\title{
Classification of the Provinces of the Black Sea Region in Terms of Beekeeping
}

\author{
Nur İlkay Abacı ${ }^{1, *}\left(\mathbb{D}\right.$, Samet Hasan Abacı ${ }^{2}$, Selim Bıyık ${ }^{2}$ \\ ${ }^{1}$ Ondokuz Mayis University, Faculty of Agriculture, Department of Agricultural Economics, Samsun, Turkey \\ ${ }^{2}$ Ondokuz Mayis University, Faculty of Agriculture, Department of Animal Science, Samsun, Turkey
}

\section{Article History}

Received 14 December 2021

Accepted 28 December 2021

First Online 29 December 2021

\section{*Corresponding Author \\ Tel.: +903623121919 \\ E-mail: ilkaysonmez55@gmail.com}

\begin{abstract}
This study aims to group the Black Sea provinces, which hold $27.48 \%$ of the honey production in Turkey, by cluster analysis. For this purpose, the number of beekeeping enterprises in the Black sea region, the total number of colonies (traditional and modern), honey production, and beeswax production data gathered from the Turkish Statistical Institute (TURKSTAT) between 2016 and 2020 were used. As a result of the analysis, the Black sea region provinces were clustered into three groups based on their colony count and production. The first group consisted of; Amasya - Gümüşhane, Bayburt - Tokat, Düzce, Bolu - Karabük provinces, and Zonguldak - Çorum, Sinop provinces. The second group consisted of; Artvin, Kastamonu - Samsun, Bartın, Giresun - Trabzon, Rize provinces. The only province in the third group was Ordu. Assessing their development levels in regards to beekeeping practices may provide an opportunity for grouping provinces that are similar in terms of their product type, especially for apitherapy, health, cosmetics, and edible products to help them specialize in certain products. Determining these groups might also make it possible to carry out training and extension programs in a more organized way. Thus, it is thought that the contribution to the country's economy will increase by providing sustainable and economic production.
\end{abstract}

\section{Introduction}

Turkey, due to its geographical structure, has suitable climate conditions and a wide variety of plants available for honey bees (Apis mellifera L.), and therefore is a suitable ecosystem for beekeeping. In addition to the production of different bee products, diversity can be seen in those products (Akkaya, 2007; Özkırım, 2018; Sorkun, 2007). These advantages of our country have supported beekeeping and contributed to the country's economy with the produced goods. (Firatlı et al., 2000). In addition to the advantages of the diverse vegetation, Turkey has an important position in the world with its genetic resources (Bodenheimer, 1942; Kandemir et al., 2000; Smith et al., 1997). Moreover,
Turkey is one of the leading countries in the world in the apiculture sector with more than 8 million colonies and advanced beekeeping practices (FAO, 2021; TURKSTAT, 2021).

The presence of genetic resources has seen as a Caucasian race (A. $m$. caucasica) in the Northeastern Anatolia Region and the Eastern Black Sea Region (Akyol et al., 2006; Bodenheimer, 1942; Dodoloğlu \& Genç, 2002; Genç et al., 1997; Palmer et al., 2000; Ruttner, 1988; Smith et al., 1997). Studies imply that the Western Black Sea Region is one of the important gene regions. The fact that the region is not on the migratory beekeeping migration routes provides an advantage in terms of breeding and preservation of breeding material. 
Beekeeping activities can be carried out in every region of Turkey with its vegetation, suitable climate, social and economic structure. Based on these facts some differences occur both in regions and in provinces depending on the advantages and disadvantages of the regions. Examples of these differences are the number of colonies, amount, and variety of products produced. In the Black Sea Region, specific vegetation has been formed depending on geography and related climatic condition, and as a result of these region-specific monofloral kinds of honey have been produced (Sıralı \& Cınbirtoğlu, 2018; Sorkun, 2007). According to 2021 Turkish Statistical Institute data, the Black Sea region accounted for 27.34 percent of the entire Turkish beekeeping enterprises. $20.74 \%$ in terms of the number of hives, $27.48 \%$ of honey production, and $17.32 \%$ of beeswax production are made by businesses in the Black Sea region provinces. $20.74 \%$ of the number of hives, $27.48 \%$ of honey production, and $17.32 \%$ of beeswax production are produced by enterprises in the Black Sea region provinces (TURKSTAT, 2021).

According to 2021 Turkish statistical institute data, Ordu province has $11.77 \%$ of the number of enterprises in the Black Sea region. The highest number of hives with a rate of $33.79 \%$ and 60,18 percent of honey produced from enterprises in Ordu. It corresponds to approximately $16.54 \%$ of the total honey production in Turkey. Even though the second number of hives are in Trabzon province around 9.89 percent, the secondhighest production is in Rize province. The lowest number of beehives $(0.89 \%)$ and honey production $(0.38 \%)$ in the region is in Karabük (TURKSTAT, 2021). Therefore, the number of colonies is an effective factor in the amount of product produced.

Financial supports for the beekeeping sector started in 2003 (Çevrimli \& Sakarya, 2018) and the Beekeeping Registration System (AKS) was valid after 2009 (Anonymous, 2020). In the apiculture sectors such as queen bee breeding, bumblebee breeding and use, honey production and beehive, and export have started to receive financial support (Çevrimli \& Sakarya, 2018). In addition, in some cases, some municipalities and beekeepers' associations are providing financial support to beekeepers, and also the Agriculture and Rural Development Support Institution (TKDK) supports beekeeping projects. However, there is no financial support to beekeepers whose bees died off due to illnesses and this creates a challenging situation for beekeepers (Anonymous, 2020). However, in recent years, production losses in beekeeping have been increasing due to the increase in input costs, forest fires, and global warming. It is thought that the same amount of support given to all provinces will not prevent these losses. For this reason, providing region-based financial support for regions similar in production might enable beekeepers to develop competitively in their own regions. Determining these groups might also make it possible to carry out training and extension programs in a more planned way. For this reason, in this study, we set out to group provinces in the Black Sea region by assessing the number of the beekeeper and the production amount together. For this purpose, we grouped the provinces in the Black Sea region based on the number of beekeeping enterprises, number of colonies, amount of honey, and beeswax production by performing cluster analysis.

\section{Materials and Methods}

Cluster analysis is one of the multivariate statistical methods that divide unknown variables into similar subgroups (Özdamar, 2004). It is aimed to classify the provinces in the Black Sea region where honey and honey products are produced. The number of beekeeping enterprises, the total number of hives (traditional and modern), the amount of honey and beeswax produced in the provinces between the years 2016-2020 obtained from TURKSTAT were used (TURKSTAT, 2021). The normality assumption of the data was analyzed with the Anderson Darling method, it was determined that while the number of enterprises showed normal distribution $(P>0.05)$, other variables did not show normal distribution $(P<0.05)$. In addition, since the units of the variables used were not the same and there were outliers in the data (due to Ordu province data), 0 - $\leq 1$ standardization was applied to the data. Afterward, Euclidean Distance values were calculated. The "Similarity Between Groups" dendrogram, which shows the similarities and differences of the provinces with each other, was obtained by performing cluster analysis according to the Average Linkage method in order to have the maximum distance between the groups and the high similarity within the group. Minitab 21 package program (trial version) was used in the analysis of the data (Minitab, LLC., 2021).

\section{Results and Discussion}

The clusters formed as a result of the clustering analysis, the similarity rates, and the findings of the number of observations in the new cluster are given in Table 1.

The dendrogram of the clusters formed as a result of the clustering analysis is given in Figure 1. 
Table 1. Amalgamation Steps

\begin{tabular}{cccccccc}
\hline Step & $\begin{array}{c}\text { Number of } \\
\text { clusters }\end{array}$ & $\begin{array}{c}\text { Similarity } \\
\text { level }\end{array}$ & $\begin{array}{c}\text { Distance } \\
\text { level }\end{array}$ & \multicolumn{2}{c}{$\begin{array}{c}\text { Clusters } \\
\text { joined }\end{array}$} & $\begin{array}{c}\text { New } \\
\text { cluster }\end{array}$ & $\begin{array}{c}\text { Number of obs. in new } \\
\text { cluster }\end{array}$ \\
\hline 1 & 17 & 98.4987 & 0.02979 & 5 & 9 & 5 & 2 \\
2 & 16 & 97.7692 & 0.04427 & 4 & 15 & 4 & 2 \\
3 & 15 & 96.5228 & 0.06901 & 4 & 6 & 4 & 3 \\
4 & 14 & 96.4725 & 0.07001 & 17 & 18 & 17 & 2 \\
5 & 13 & 96.1447 & 0.07651 & 1 & 8 & 1 & 2 \\
6 & 12 & 93.6908 & 0.12522 & 1 & 4 & 1 & 2 \\
7 & 11 & 93.6129 & 0.12676 & 10 & 13 & 10 & 3 \\
8 & 10 & 91.4496 & 0.16970 & 14 & 17 & 14 & 7 \\
9 & 9 & 90.9000 & 0.18060 & 1 & 5 & 1 & 3 \\
10 & 8 & 90.2746 & 0.19302 & 2 & 10 & 2 & 2 \\
11 & 7 & 89.2590 & 0.21317 & 7 & 16 & 7 & 10 \\
12 & 6 & 86.8799 & 0.26039 & 2 & 3 & 2 & 3 \\
13 & 5 & 86.5511 & 0.26692 & 1 & 14 & 1 & 7 \\
14 & 4 & 81.2578 & 0.37197 & 7 & 12 & 7 & 17 \\
15 & 3 & 77.6000 & 0.44456 & 2 & 7 & 2 & \\
16 & 2 & 70.0817 & 0.59378 & 1 & 2 & 1 & \\
17 & 1 & 13.8742 & 1.70931 & 1 & 11 & 1 & \\
\hline
\end{tabular}

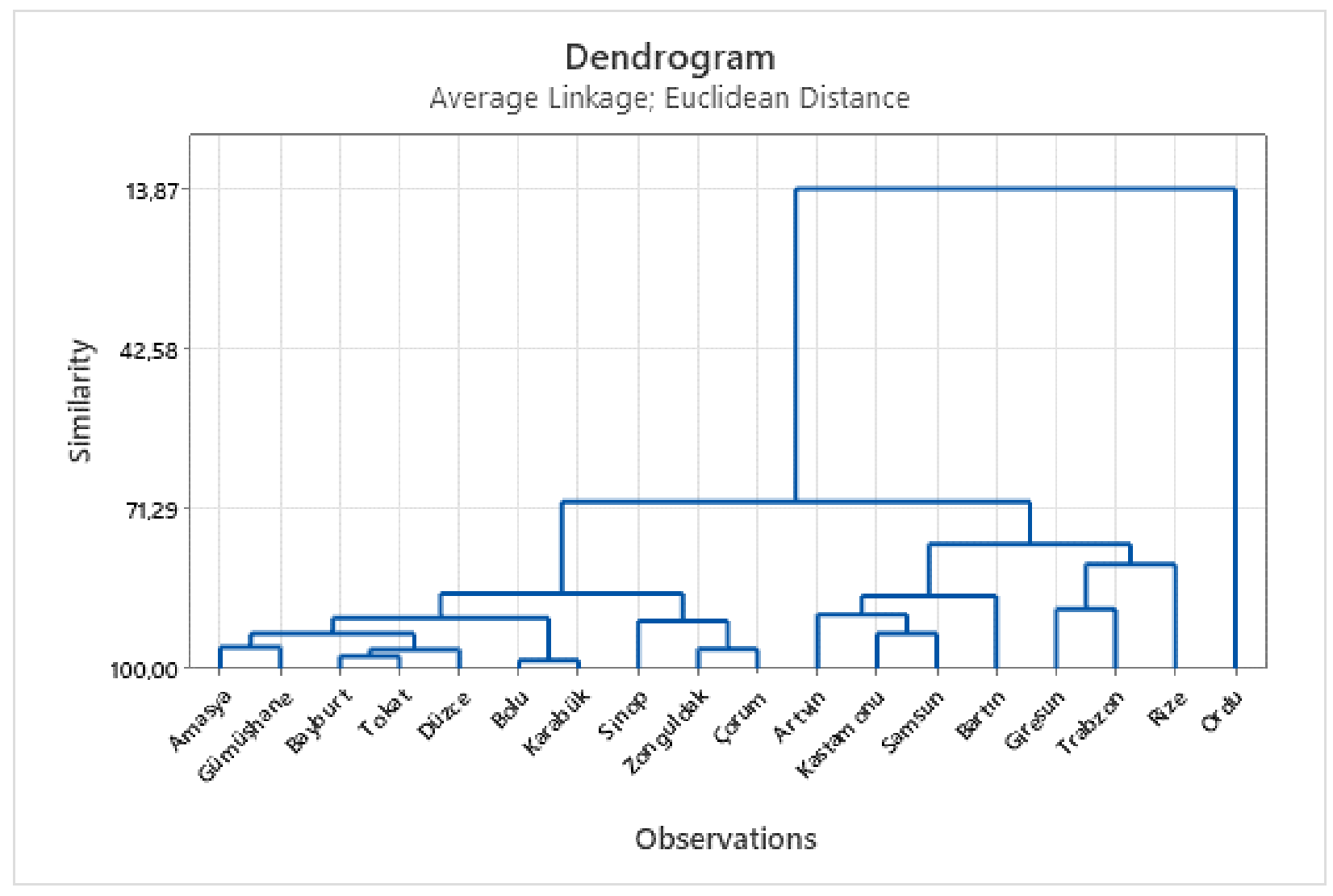

Figure 1. Dendrogram of Cluster Analysis 
According to the results of the analysis, the similarity between the provinces in the Black Sea region can be grouped into different three clusters. Amasya Gümüşhane provinces formed a subset with $96.15 \%$ similarity. The subset of Bayburt and Tokat provinces is similar to each other with a rate of $97.77 \%$. Düzce was included in these provinces with a similarity of $96.53 \%$. It was determined that the similarity between Amasya Gümüşhane provinces and Bayburt, Tokat Düzce provinces was $93.69 \%$ and a new subset was formed. Bolu and Karabük provinces formed a subset with 98.51\% similarity, and Bolu - Karabük provinces were found to be included in Amasya - Gümüşhane, Bayburt Tokat, Düzce provinces with $90.91 \%$ similarity. Zonguldak - Çorum provinces formed a subset with 96.48\% similarity, and Sinop province was included in this subset with $91.45 \%$ similarity. Amasya Gümüşhane, Bayburt - Tokat, Düzce, Bolu - Karabük provinces, Zonguldak - Çorum, Sinop provinces were included with $86.55 \%$ similarity, and the first cluster consisting of 10 provinces was formed.

A subset was formed with a similarity of $93.62 \%$ to Kastamonu-Samsun province, Artvin and Bartın were included in this subset with a similarity of $90.28 \%$, $86.88 \%$ respectively. Giresun and Trabzon formed a subset with $89.26 \%$ similarity and Rize entered this subset with $81.26 \%$ similarity. The similarity between the provinces of Artvin, Kastamonu - Samsun, Bartın, and Giresun - Trabzon, Rize was determined to be $77.61 \%$ and the second cluster consisting of 7 provinces was formed.

It was determined that beekeeping and bee products production in Ordu province differed from other provinces and Ordu province alone formed the third cluster.

The beekeeping sector is developing day by day in Turkey and the world, and its economic return and product diversity are increasing. The number of hives and honey production in Turkey increases every year, but there is a decline in productivity (Çevrimli \& Sakarya, 2018). For this reason, Abaci et al. (2020) reported that the number of hives will increase in Turkey in the next 5 years compared to 2018 , and they were successful with an average deviation of $0.51 \%$ in their predictions for the first 2 years of this prediction. In addition, a 7-year prediction was made by Burucu and Gülse Bal (2017) for honey production and it was stated that honey production would increase, and it was determined that honey production increased from 2017 to 2020 according to the TURKSTAT 2021 data. Compared to 2018, there was a $1.82 \%$ decrease in 2019 and a $7.15 \%$ decrease in 2020 (Abacl et al., 2020; TURKSTAT, 2021).

Keleş et al. (2019) in the study conducted by the Agriculture and Rural Development Support Institution (TKDK) on the investigation of the effectiveness of beekeeping grants within the scope of the European Union Pre-Investment Assistance Instrument Rural Development Program (IPARD) in Trabzon, IPARD's supports could not fully achieve their goal. The reasoning is that the errors originate from the enterprise and the institution.

Günbey and Cengiz (2021) investigated the performance of some honey bee genotypes under regional conditions. Okuyan et al. (2020) determined the antioxidative effects of propolis collected from Samsun province. Kuvancl et al. (2017) investigated the status of beekeeping activities (migratory beekeeping, local beekeeping, production, loss) in the Eastern Black Sea region. They suggested that beekeepers should follow the developments and innovations in beekeeping to increase their knowledge level and get technical support when necessary. Güler (2021), in his study to determine the efficiency of beekeeping according to the provinces in Turkey, found that the provinces with enterprises with more than the average number of hives in Turkey are productive. However, it has been reported that the efficiency value is high in the provinces above the honey yield average of Turkey $(13 \mathrm{~kg})$. These results show that efficiency values differ according to the scale of the enterprise and honey yield and that large-scale beekeeping enterprises are advantageous in terms of efficiency. For this reason, Turkey and the regional beekeeping sector have many technical and economic problems, especially low yield.

\section{Conclusion}

Supports given to beekeeping are made per hive. Despite the increase in the number of hives, the decrease in the yield per colony increases the production costs. In addition, small businesses do not fully take advantage of the supports. Therefore, the supports cannot reach their purpose completely.

The provinces of the Black Sea region, which accounted for $27.48 \%$ of the total honey production in Turkey, are divided into 3 clusters in terms of beekeeping and production. The first cluster consists of Amasya - Gümüşhane, Bayburt - Tokat, Düzce, Bolu Karabük provinces and Zonguldak - Çorum, Sinop provinces. The second cluster consists of the provinces of Artvin, Kastamonu - Samsun, Bartın, Giresun Trabzon, Rize. The third cluster consisted only of Ordu province.

Starting from the lowest groups of the clusters determined in this study, plans should be made to ensure competitiveness with support policies, production plans, and producer organizations of beekeeping products in similar provinces. By determining the development status of these clusters in terms of beekeeping, provinces similar to each other can be specialized, especially in terms of products produced in the field of apitherapy, health, cosmetics, and food. With the determination of these regions, training and extension studies can be carried out in a more planned way to adopt production and innovations in those regions. Moreover, cooperation can be established between breeders in sub-cluster provinces. With the specialization of the producers in the provinces, a higher 
quality product can be provided for the consumers. Thus, producers can produce products with high economic returns. It can be thought that sustainable and economic production will much contribute to the country's economy.

\section{Acknowledgement}

The authors are grateful to Samet Okuyan and Serhat Solmaz for their contribution to the manuscript.

\section{References}

Abacı, N. İ., Abacı, S. H., \& Bıyık, S. (2020). Forecast for the Number of Colonies and Honey Yield in Turkey. Turkish Journal of Agriculture-Food Science and Technology, 8(2), 464-470.

Anonymous, 2020. Arıcılık raporu. Ordu Ticaret Borsası, https://www.ordutb.org.tr/wpcontent/uploads/2020/10/Aricilik-Raporu.pdf

Akkaya, H. (2007). Beekeeping in Anatolia from the Hittites to the present day. Journal of Apicultural Research, 46(2), 120-124.

Akyol, E., Şahinler, N., \& Özkök, D. (2006). Honeybee (Apis mellifera) races, ecotypes and their general characteristics in Turkey. $J$. Anim. and Veter. Advances, 5(9), 771-774.

Bodenheimer, F. S. (1942). Studies on the honeybee and beekeeping in Turkey. Merkez Zirai Mücadele Enstitüsü Ankara, Turkey.

Burucu, V., \& Gülse Bal, H. S. (2017). Türkiye'de arıcılığın mevcut durumu ve bal üretim öngörüsü. Tarım Ekonomisi Araştırmaları Dergisi, 3(1), 28-37.

Çevrimli, M. B., \& Sakarya, E. (2018). Türkiye arıcılık sektöründe mevcut durum, sorunlar ve çözüm önerileri. Erciyes Üniversitesi Veteriner Fakültesi Dergisi, 15(1), 58-67.

Dodoloğlu, A., \& Genç, F. (2002). Kafkas ve Anadolu Balarısı ırkları ile karşılıklı melezlerinin bazı fizyolojik özellikleri. Turk. J. Vet. Anim. Sci, 26, 715-722.

FAO, (2021). Food and Agriculture Organization of the United Nations Classifications and Standards. http://faostat.fao.org

Fıratlı, Ç., Genç, F., Karacaoğlu, M., \& Gencer, H. V. (2000). Türkiye Arıcılığının Karşılaştırmalı Analizi Sorunlar-Öneriler. V. Türkiye Ziraat Mühendisliği Teknik Kongresi, 17-21.

Genç, F., Dülger, C., Kutluca, S., \& Dodoloğlu, A. (1997). Kafkas, Anadolu ve Erzurum balarısı (Apis Mellifera I.) genotiplerinin bazı morfolojik özelliklerinin belirlenmesi. Atatürk Üniversitesi Ziraat Fakültesi Dergisi, 28(5), 683-697.

Güler, D. (2021). Türkiye'de Illere Göre Arıcılık Etkinliğinin Veri Zarflama Analizi ile Belirlenmesi. Uludağ Arıcılık Dergisi, 21(2), 146-156.

Günbey, B., \& Cengiz, F. Karadeniz Bölgesindeki Bazı Bal Arısı (Apis mellifera L.) Genotiplerinin Bölge Koşullarındaki Performansları. Ziraat Mühendisliği, 371, 113-123.

Kandemir, I., Kence, M., \& Kence, A. (2000). Genetic and morphometric variation in honeybee (Apis mellifera) populations of Turkey. Apidologie, 31, 343-356.

Keleş, O. C., Demir, N., \& Eyduran, E. (2019). Trabzon ilinde IPARD programı kapsamındaki arıcılık hibelerinin etkinliğinin belirlenmesi. SETSCI Conference Proceedings, 4(8), 203-207. doi: https://doi.org/10.36287/setsci.4.8.037.

Kuvancı, A., Yılmaz, F., Öztürk, S. H., Konak, F., \& Buldağ, M. (2017). Doğu Karadeniz Bölgesi Arıcılığına Genel Bakış. Arıcılık Araştırma Dergisi, 9(2), 47-55.

Minitab, LLC. (2021). [Computer software]. State College, PA: Minitab, Inc.

Okuyan, S., Mehmetoğlu, S., \& Çakıcı, N. (2020). Antioxidant Variability of Propolis Collected from Different Zones in Hives. Bee Studies, 12(1), 1-4.

Özdamar, K. (2004). Paket Programlar ile Istatistiksel Veri Analizi (Çok Değişkenli Analizler). Kaan Kitabevi.

Özkırım, A. (2018). Beekeeping in Turkey: Bridging Asia and Europe. In Chantawannakul, P., Williams, G., \& Neumann, P. (Eds.), Asian Beekeeping in the 21st Century (pp.41-69). Springer Nature Singapore Pte Ltd.

Palmer, M. R., Smith, D. R., \& Kaftanoglu, O. (2000). Turkish honeybees: genetic variation and evidence for a fourth lineage of Apis mellifera mtDNA. Heredity, 91, 42-46.

Ruttner, F. (1988). Biogeography and Taxonomy of Honeybees. Springer.

Sıralı, R., \& Cınbırtoğlu, Ş. (2018). Ormangülü (Rhododendron) Türlerinin Bazı Özellikleri ve Arıcılık Açısından Önemi. Journal of Apiculture Research, 10(2), 45-53.

Smith, D.R., Slaymaker, A., Palmer, M., \& Kaftanoglu, O. (1997). Turkish honeybees belong to the east Mediterranean mitochondrial lineage. Apidologie, 28, 269-274.

Sorkun, K. (2007). Türkiye'nin Nektarlı Bitkileri Polenleri ve Balları. Palme Yayınevi.

TURKSTAT (2021). Turkish Statistical Institute. http://www.tuik.gov.tr 